\title{
BIOTRANSFORMATION OF C-5 AND C-6 SUGARS OF CELLULOSIC COTTON WASTES TO BIOETHANOL THROUGH PHYSICAL AND ENZYMATIC MODES
}

\author{
RAJALAKSHMI, . $^{1 *}-$ KARTHIKSUNDARAM, S. ${ }^{1}-$ POORNIMA, D. ${ }^{1}$ - RAJENDRAN, R. ${ }^{1}$ \\ ${ }^{l}$ Department of Microbiology, PSG College of Arts \& Science \\ Coimbatore- 641 014, India \\ (phone:+91-822-024-5359) \\ *Corresponding author \\ e-mail: raji.ajjii@gmail.com \\ (Received $12^{\text {th }}$ Nov 2015; accepted $5^{\text {th }}$ Mar 2016)
}

\begin{abstract}
The present research focuses on the feasibility of utilizing cotton waste for energy resurgence after physical and biological pretreatment followed by simultaneous saccharification and fermentation processes (SSF). The cotton waste was pretreated with microwave irradiation (MW) and subsequently subjected to enzymatic hydrolysis for the release of sugars utilizing the cellulase enzyme producer Trichoderma reesei (MTCC 164). Based on Box-Behnken design, $\mathrm{pH}$, temperature and hydrolysis time period were selected as the most significant variables for the production of cellulase. The simultaneous fermentation and enzymatic saccharification (SSF) of pretreated substrate with immobilized Saccharomyces cerevisiae (MTCC 172) yielded 2.65\%, 1.48\% and $1.32 \%$ of ethanol with hard waste, carding waste and cotton seed waste, respectively. The findings suggest that these cotton wastes can be used effectively for the ethanol production.
\end{abstract}

Keywords: cotton waste, SSF, cellulase production, pre-treatment, Box-Behnken design, ethanol

\section{Introduction}

Globally, ethanol has become an immediate viable alternative for the rapidly exhausting fossil fuel deposits, and increasing concerns over the everlasting environmental pollution (Galbe and Zacchi, 2002). An extensive range of substrates can be used as feedstock for ethanol production, comprising fermentable sugars in the form of lignocellulosic wastes through series of steps involved in the reduction of complex polysaccharides. Furthermore, cellulosic biomasses are the most abundant in the world and thus, are now being considered as one of the best substitute raw materials for the production of ethanol (Jorgensen et al., 2007). India has large number of cotton fabrics manufacturing industries in the world. The difficulty of disposing the final scrape from these industries has now assumed serious dimensions, as it has no salability and poses pollution hazards (Raj et al., 2009). Bioconversion of these cotton wastes into valuable product such as ethanol could be considered as suitable solution.

The basic idea in pretreatment technology of cotton waste in the bioconversion process is to alter or remove lignin and hemicelluloses, increasing the surface area and decreasing the crystallinity of cellulose (Zhu et al., 2009). Degradation or loss of carbohydrate and formation of inhibitory by-products should also be considered during pretreatment (Taherzadeh et al., 2007). Microwave irradiation has high heating efficiency, and thus it is able to degrade cellulose and hemicelluloses as well as increase in enzymatic susceptibility (Zhu, 2005). Microwave heats the target object directly by applying an electromagnetic field to dielectric molecules as compared to conduction/convection heating which is based on intramolecular heat transfer 
(Newnham et al., 1991). Several researchers have used microwave pretreatment as a potential method for pretreatment of various lignocellulosic materials (Alvira et al., 2010; Shi et al., 2011; Jackowiak et al., 2011) and to damage the recalcitrant lignin (Hu and Wen, 2008). Further fermentation of the hydrolysate will help to yield ethanol using fermenting microorganisms.

SSF has gained a lot of concern, as it is both logistically and cost-effectively favorable in terms of higher ethanol yield (Tomas-Pejo et al., 2009). The processes usually employed in the fermentation of lignocellulosic hydrolysate are Simultaneous saccharification and fermentation (SSF) and separate hydrolysis and fermentation (SHF). Conventionally or traditionally the SHF process has been employed but SSF is superior for ethanol production since it can improve ethanol yields by removing end product inhibition and eliminate the need for separate reactors. It is also cost effective but difference in optimum temperature conditions of enzyme for hydrolysis and fermentation poses a few limitations. The higher ethanol yield coefficient from SSF would be partially due to more conversion of xylose to xylitol under the SSF conditions (Sarkar et al., 2012). Hydrolysis is usually the rate limiting step in SSF (Philippids and Smith, 1995). In SSF, cellulases and xylanases convert the carbohydrate polymers to fermentable simple sugars. These enzymes are extremely susceptible to feedback inhibition by the products such as glucose, xylose, cellobiose, and other oligosaccharides. The advantage of SSF is that, a saccharification and ethanol fermentation is concurrently carried out in a single vessel (Hasunuma and Kondo, 2012). To achieve a high ethanol concentration from cellulosic materials in a SSF system, a high substrate loading is required, which results in high insoluble solids content in the system. A major concern in the SSF process is fast liquefaction of cellulose to overcome the mixing problem at high loadings of cellulosic materials for microbial simultaneous fermentation of releasing glucose. Therefore, microwave pretreated biomass subjected to enzymatic saccharification in a high substrate concentration; SSF enhances the yield of ethanol production. Against this background, the present study was carried out to analyze the use of cellulase producing $T$. reese $i$ (MTCC 172) and S. cerevisiae (MTCC 164) in the conversion of cotton waste to bioethanol.

\section{Materials and methods}

\section{Fermentable substrates and cultures}

Cotton wastes were collected from textile mills in and around Coimbatore, Tamilnadu, India. The wastes were mechanically processed to reduce the length of the fibres and also to eliminate the debris. The fibers were boiled in water at $100^{\circ} \mathrm{C}$ for 30 min. Subsequently, the fibers were rinsed with deionized water and air-dried. The cultures, T. reesei (MTCC 164) and S. cerevisiae (MTCC 164) were obtained from Microbial Test Culture Centre (MTCC), Chandigarh, India. The cultures were revived in the Czapek-Dox broth for further analysis.

\section{Microwave pretreatment of cotton waste and compositional analysis}

Exactly $5 \mathrm{~g}$ of each type of cotton waste (Cotton seed waste-CSW, Carding waste$\mathrm{CW}$ and Hard waste-HW) in $500 \mathrm{ml}$ of distilled water was placed at the center of the rotating platform in the microwave oven for $5,10,15,20,25$ and $30 \mathrm{~min}$ in a general 
purpose laboratory microwave oven (Godrej appliances, model: GMX 20GA1 MIZ) at $230 \mathrm{~V}$ and $\sim 50 \mathrm{~Hz}$ (Keshwani et al., 2007). After treatment, the cotton wastes were filtered and shade dried The moisture, cellulose and hemi-cellulose contents of the cotton wastes were determined as per to ASTM test methods (1995). DNS method of Miller (1959) was used to estimate reducing sugars.

\section{Optimization and purification of cellulase enzyme by T. reesei}

The experimental design and statistical analysis were performed employing RSM Box-Behnken experimental design using Design-Expert software (Trial Version 7.1.5, Stat-Ease, Minneapolis, 2008) for optimizing the $\mathrm{pH}$, temperature and incubation time for the production of cellulase enzyme. The design matrix with 17 experimental runs in two blocks and triplicates for the midpoint was used for the experiment. The culture was grown for $72 \mathrm{~h}$ at $30^{\circ} \mathrm{C}$ in Czapek- Dox broth and was used for further analyses. The partial purification of the culture medium was performed using dialysis. The enzyme produced under optimal condition was dialysed using dialysis membrane. The dialysed cellulase enzyme was further checked for their activity using spectrophotometric assay method.

\section{Immobilization of S. cerevisiae}

Exactly $50 \mathrm{ml}$ of sodium alginate solution $\left(7.2 \%\right.$ in distilled $\left.\mathrm{H}_{2} \mathrm{O}\right)$ was mixed with equal volume of distilled $\mathrm{H}_{2} \mathrm{O}$ containing $0.1 \mathrm{ml}$ of overnight yeast extract broth culture of $S$. cerevisiae (MTCC 172) and was gradually dropped into $0.1 \mathrm{M} \mathrm{CaCl}_{2}$ solution for the formation of sodium alginate beads. The beads were stored at $4{ }^{\circ} \mathrm{C}$ after washing with distilled $\mathrm{H}_{2} \mathrm{O}$. The viability of the immobilized $S$. cerevisiae cells was verified as per standard procedure (Duarte et al., 2013).

\section{Simultaneous saccharification and fermentation (SSF)}

To $100 \mathrm{ml}$ of fermentation broth [yeast peptone dextrose broth (YPDB)], $2.5 \mathrm{~g}$ of pretreated cotton waste, $1 \mathrm{ml}$ of dialyzed cellulase enzyme and $0.1 \mathrm{~g}$ of $S$. cerevisiae sodium alginate beads were added with fermentation broth and incubated for 7 days at $37^{\circ} \mathrm{C}$ in shaker. After incubation, the ethanol production was estimated by Williams and Darwin dichromate method (Williams and Darwin, 1950).

\section{Results and Discussion}

\section{Microwave pretreatment of cotton wastes}

The microwave irradiation for 5 mins proved to be efficient in releasing free glucose from cotton wastes (Table 1). From the results, it is evident that $5 \mathrm{~min}$ of MW irradiation released $140 \mathrm{mg} / \mathrm{ml}, 165 \mathrm{mg} / \mathrm{ml}$ and $180 \mathrm{mg} / \mathrm{ml}$ of glucose from CSW, CW and HW, respectively. Zhu et al. (2009) reported that microwave irradiation at a power of up to $700 \mathrm{~W}$ at various exposure times resulted in weight loss due to the degradation of cellulose, hemicelluloses and lignin. Microwave pretreatment increasing the yield of total available reducing sugars has been reported by (Azuma et al., 1984); (Kitchaiya et al., 2003); (Ooshima et al., 1984). Lin et al. (2012) stated that microwave irradiation of cotton waste is an alternative approach to heating. 
Table 1. Glucose concentration of microwave pretreated cotton waste

\begin{tabular}{cccc} 
Time of & \multicolumn{3}{c}{ Glucose Concentration $(\mathrm{mg} / \mathrm{ml})$} \\
\cline { 2 - 4 } $\begin{array}{c}\text { exposure } \\
\text { (min) }\end{array}$ & CSW & CW & HW \\
\hline 0 & 70 & 80 & 100 \\
5 & 145 & 175 & 185 \\
10 & 140 & 165 & 180 \\
15 & 135 & 125 & 130 \\
20 & 130 & 130 & 160 \\
25 & 100 & 110 & 115 \\
30 & 100 & 100 & 120
\end{tabular}

\section{Compositional analysis of cotton waste}

The compositional analysis showed that the cellulose and hemicelluloses content (\%) decreased after five minutes of microwave irradiation of the cotton waste (Table 2). The results prove that the pretreatment aids in the conversion of the complex polysaccharides into simple sugars so as to aid in the subsequent fermentation process. It was also noted that, there was 7\%,5\% and 5.6\% decrease in the moisture content for CSW, CW and HW wastes, respectively after the microwave treatment. The carding waste and hard waste recorded maximum reduction of cellulose (15\%) and hemicelluloses (10\%) after microwave irradiation. Exactly, $13.84 \%$ and $10.40 \%$ increase of free sugar in hard waste and carding waste respectively, was noted. There was $6.1 \%$ and $6.9 \%$ decrease acid residues in cotton seed waste and hard waste respectively after pre-treatment. In a similar study, Venkatramanan et al. (2014) stated that the moisture content and acid insoluble residue was $12.63 \%$ and $17.84 \%$, respectively, in untreated cotton waste.

Table 2. Compositional contents of cotton waste

\begin{tabular}{ccccccc} 
Treatments & Cotton Type & \multicolumn{5}{c}{ Compositional analysis } \\
\cline { 3 - 7 } & & $\begin{array}{c}\text { Moisture } \\
\text { content } \\
\%\end{array}$ & $\begin{array}{c}\text { Cellulose } \\
\%\end{array}$ & $\begin{array}{c}\text { Hemicelluloses } \\
\%\end{array}$ & $\begin{array}{c}\text { Free } \\
\text { sugars } \\
\text { mg/ml }\end{array}$ & $\begin{array}{c}\text { Acid } \\
\text { residue } \\
\%\end{array}$ \\
\hline $\begin{array}{c}\text { Before } \\
\text { pretreatment }\end{array}$ & CSW & 15.30 & 57 & 10 & 20.21 & 18.70 \\
& CW & 14.60 & 59 & 11 & 24.40 & 15.40 \\
After & HW & 8.80 & 68 & 16 & 41.32 & 7.20 \\
pretreatment & CSW & 8.30 & 42 & 04 & 30.61 & 11.20 \\
& CW & 9.60 & 51 & 07 & 33.17 & 9.30 \\
& HW & 3.20 & 45 & 06 & 55.16 & 0.32
\end{tabular}

\section{Analysis of response surface, enzyme production and hydrolysis}

The results showed that the independent factors viz., temperature and incubation time had significant effect on the enzyme production. The quadratic term of the three different factors namely, temperature, $\mathrm{pH} \&$ incubation time also had a significant effect (Table 3). The regression model for the enzyme activity noted to be significant ( $p<$ $0.01)$ with satisfactory value of 0.8849 as co-efficient of determination $\left(\mathrm{R}^{2}\right)$. The result 
indicates a good agreement between experimental and predicted values and implies the statistical model is reliable for enzyme production. Response surface plots (Fig. 1-2) depict that the hydrolysis time and temperature significantly affect the enzyme production. The two dimensional contour plot with respect to $\mathrm{pH}$ and incubation time showed sloping nature on the plot, suggesting that temperature and hydrolysis time was interdependent. This proves that incubation time for enzyme production is dependent on the temperature. However, the shapers of the response surface curves indicate no positive interaction between temperature \& incubation time and $\mathrm{pH} \&$ incubation time. The correlation between predicted and measured values validates the model and existence of an optimal point. "Prob > F" value less than 0.0500 indicate model terms are significant. The analysis of variance showed that this regression model is significant $(p<0.01)$ with $\mathrm{F}$ value of 14.66 . There was only a $0.01 \%$ chance that a "Model FValue" was insignificant which largely could occur due to noise. Values of "Prob $>$ F" less than 0.0500 indicated that the model terms were significant. In this case A, B, A2 and C2 were significant model terms. Values greater than 0.1000 indicated that the model terms were not significant. The lack of fit value of 0.067 is not significant hence the model was perfectly fit (Table 4 and 5). "Adeq Precision" i.e., signal to noise ratio was 13.85 which indicated an adequate signal. Hence, this model could be used to navigate the design space. The maximum cellulase activity of $2.76 \mathrm{IU} / \mathrm{ml}$ was recorded at $\mathrm{pH} 4$, temperature $25^{\circ} \mathrm{C}$ at $78 \mathrm{~h}$. Our results are in accordance with Das et al. (2015) who stated that, optimization of cellulase enzyme production by Box- Behnken design showed that all the three factors plays viz., $\mathrm{pH}$, temperature and incubation time play an important role in the cellulase enzyme activity.

Table 3. Box-Behnken Experimental design with different variables

\begin{tabular}{c|c|c|c|c} 
& \multicolumn{5}{|c}{ Variables } \\
\cline { 2 - 5 } Runs & $\begin{array}{c}\text { Temperature } \\
\mathbf{C}\end{array}$ & $\begin{array}{c}\mathbf{p H} \\
\mathbf{( B )}\end{array}$ & $\begin{array}{c}\text { Incubation time } \\
\text { (h) }\end{array}$ & $\begin{array}{c}\text { Enzyme activity } \\
\text { IU/ml }\end{array}$ \\
& & & $(\mathbf{C})$ & \\
\hline 1 & 40 & 6.5 & 78 & 0.80 \\
2 & 55 & 6.5 & 144 & 0.10 \\
3 & 40 & 9 & 12 & 0.11 \\
4 & 25 & 6.5 & 12 & 0.30 \\
5 & 40 & 6.5 & 78 & 0.51 \\
6 & 55 & 9 & 78 & 0.27 \\
7 & 40 & 4 & 12 & 2.55 \\
8 & 25 & 9 & 78 & 2.76 \\
9 & 55 & 4 & 78 & 2.64 \\
10 & 40 & 4 & 144 & 2.27 \\
11 & 40 & 6.5 & 78 & 0.67 \\
12 & 25 & 6.5 & 144 & 1.78 \\
13 & 40 & 6.5 & 78 & 0.66 \\
14 & 55 & 6.5 & 12 & 0.39 \\
15 & 40 & 6.5 & 78 & 0.75 \\
16 & 40 & 9 & 144 & 0.20 \\
17 & 25 & 4 & 78 & 2.65
\end{tabular}




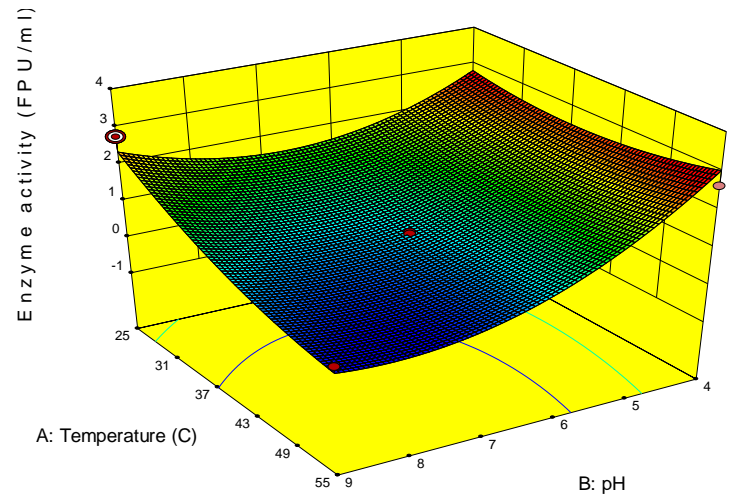

Figure 1. Effect of incubation time on enzyme production using T. reesei

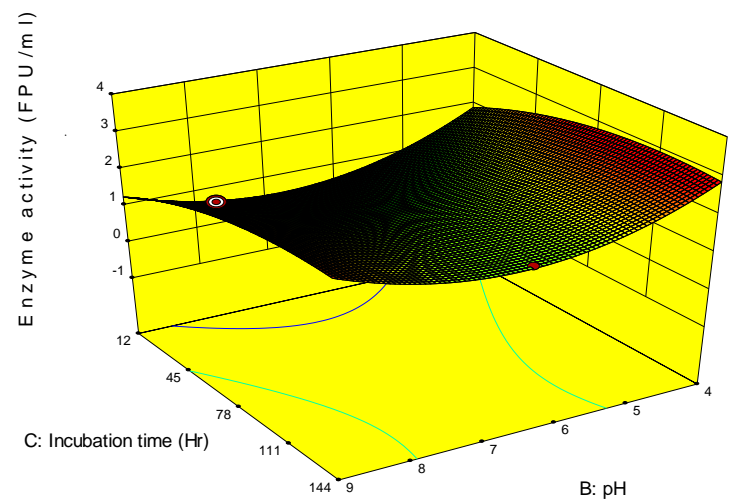

Figure 2. Effect of temperature on enzyme production using T.reesei

Table 4. ANOVA of surface quadratic model

ANOVA for Response Surface Quadratic model

\begin{tabular}{|c|c|c|c|c|c|c|}
\hline \multicolumn{7}{|c|}{ Analysis of variance table [Partial sum of squares - Type III] } \\
\hline \multirow{2}{*}{ Source } & \multirow{2}{*}{$\begin{array}{l}\text { Sum of } \\
\text { Squares }\end{array}$} & \multirow{2}{*}{ df } & \multirow{2}{*}{$\begin{array}{l}\text { Mean } \\
\text { Square }\end{array}$} & \multirow{2}{*}{$\begin{array}{c}\mathbf{F} \\
\text { Value }\end{array}$} & \multirow{2}{*}{$\frac{\text { p-value }}{\text { Prob > F }}$} & \\
\hline & & & & & & \\
\hline Model & 16.11 & 9 & 1.79 & 14.66 & 0.0009 & Significant \\
\hline A & 1.85 & 1 & 1.85 & 15.13 & 0.0060 & \\
\hline $\mathrm{B}$ & 6.15 & 1 & 6.15 & 50.40 & 0.0002 & \\
\hline $\mathrm{C}$ & 0.12 & 1 & 0.12 & 1.01 & 0.3481 & \\
\hline $\mathrm{AB}$ & 1.53 & 1 & 1.53 & 12.57 & 0.0094 & \\
\hline $\mathrm{AC}$ & 0.78 & 1 & 0.78 & 6.38 & 0.0395 & \\
\hline $\mathrm{BC}$ & 0.033 & 1 & 0.033 & 0.27 & 0.6208 & \\
\hline $\mathrm{A}^{\wedge} 2$ & 0.60 & 1 & 0.60 & 4.94 & 0.0617 & \\
\hline $\mathrm{B}^{\wedge} 2$ & 4.38 & 1 & 4.38 & 35.84 & 0.0005 & \\
\hline $\mathrm{C}^{\wedge} 2$ & 0.72 & 1 & 0.72 & 5.91 & 0.0454 & \\
\hline Residual & 0.85 & 7 & 0.12 & & & \\
\hline Lack of Fit & 0.80 & 3 & 0.27 & 21.31 & 0.0064 & \\
\hline Pure Error & 0.050 & 4 & 0.013 & & & \\
\hline Cor Total & 16.97 & 16 & & & & \\
\hline
\end{tabular}


Table 5. ANOVA of the first-order regression model

\begin{tabular}{|c|c|c|c|c|c|}
\hline \multicolumn{6}{|c|}{ Lack of Fit Tests } \\
\hline Source & $\begin{array}{l}\text { Sum of } \\
\text { Squares }\end{array}$ & Df & $\begin{array}{c}\text { Mean } \\
\text { Square }\end{array}$ & $\begin{array}{c}\text { F } \\
\text { Value }\end{array}$ & $\begin{array}{c}\text { p-value } \\
\text { Prob > F }\end{array}$ \\
\hline Linear & 8.79 & 9 & 0.98 & 77.65 & 0.0004 \\
\hline $2 \mathrm{FI}$ & 6.45 & 6 & 1.07 & 85.40 & 0.0004 \\
\hline Quadratic & 0.80 & 3 & 0.27 & 21.31 & 0.0064 \\
\hline Cubic & 0.000 & 0 & 0.013 & & \\
\hline Pure Error & 0.050 & 4 & & & \\
\hline
\end{tabular}

The results of cellulase hydrolysis of the MW irradiated cotton waste at different exposure times showed that maximum of $665 \mathrm{mg} / \mathrm{ml}$ (M2), $670 \mathrm{mg} / \mathrm{ml}$ (M1) and 910 $\mathrm{mg} / \mathrm{ml}(\mathrm{M} 2)$ of reducing sugars were released from $\mathrm{CS}, \mathrm{CW}$ and $\mathrm{HW}$, respectively (Table 6). The data proves that the enzymatic treatment enhances the release of sugars from the MW irradiated cotton wastes. From the Table 6 it is evident the HW yielded more reducing sugars after enzymatic treatment compared to CS and CW. Hence the HW irradiated with MW for 10 minutes was selected for further analysis. Enzymatic hydrolysis is cost effective because it produces better yield than acid hydrolysis and also the cost of enzyme is subsequently reduced by using advanced technologies in enzyme industries (Pan et al., 2005).

Table 6. Biological treatment of pretreated cotton waste.

\begin{tabular}{cccccccc}
\multirow{2}{*}{$\begin{array}{c}\text { MW } \\
\text { irradiated } \\
\text { cotton waste }\end{array}$} & \multicolumn{7}{c}{$\begin{array}{c}\text { Release of reducing sugars (mg/ml) } \\
\text { after cellulase treatment }\end{array}$} \\
\cline { 2 - 8 } & M0 & M1 & M2 & M3 & M4 & M5 & M6 \\
\hline CS & 100 & 650 & 665 & 660 & 620 & 545 & 540 \\
CW & 100 & 670 & 665 & 660 & 650 & 600 & 540 \\
HW & 210 & 850 & 910 & 890 & 710 & 750 & 730
\end{tabular}

M0- Control, M1- Exposure time $5 \mathrm{~min}$, M2- Exposure time $10 \mathrm{~min}$, M3- Exposure time $15 \mathrm{~min}$, Exposure time $20 \mathrm{~min}, \mathrm{M} 5$ - Exposure time $25 \mathrm{~min}$, M6- Exposure time $30 \mathrm{~min}$.

\section{Simultaneous Saccharification and Fermentation (SSF)}

The SSF resulted in maximum ethanol production of $2.65 \%$ with MW irradiated and enzymatically treated HW. All the untreated cotton wastes yielded poor percentage $(0.02-0.11 \%)$ of ethanol. The increase in the ethanol yield with cotton wastes was in the order of as MW irradiated>enzymatically treated>combinatorial MW and enzymatic treatment (Table 7).

In this process, the glucose produced by the hydrolyzing enzyme is consumed instantly by the fermenting microorganism present in the culture. Since the inhibition effects of cellobiose can be minimized by keeping low concentration of these sugars in the media. SSF gives higher reported ethanol yields from cellulose than SHF and requires low amount of enzyme (Eklund and Zacchi, 1995). Hahn-Hagerdal et al. (2006) 
has stated that $S$. cerevisiae is the most commonly and conventionally used microorganism for fermenting ethanol from sugar based residues at industrial scales and accordingly the same culture is used in the present study. The fermentation process correlated with the report of Tengborg et al. (2000) which states that, the optimum conditions for fermentation using $S$. cerevisiae at $38{ }^{\circ} \mathrm{C}$ comprises the optimal conditions for hydrolysis. Unfortunately, the ethanologenic species, S. cerevisiae cannot ferment the C5 sugars into ethanol efficiently. If only hexose sugars from cellulosic biomass are fermented, (with pentose sugars left behind) feedstock consumption for bioethanol production will be significantly high, and in the interim the unfermented pentoses will remain with the distillage. On the other hand, it will increase energy consumption in the treatment of the distillage (Zhao et al., 2012). Hence research in this area is highly imperative, since efficient conversion of both C-5 and C-6 sugars is necessary to maximize ethanol yield under controlled costs.

Table 7. Percentage ethanol production of pretreated cotton waste (SSF) Samples

Percentage Ethanol Yield (\%)

\begin{tabular}{lcccc}
\cline { 2 - 5 } & Control & Microwave & Biological & Microwave + Biological \\
\hline Cotton seed waste & 0.02 & 0.10 & 0.25 & 1.32 \\
Carding waste & 0.10 & 0.24 & 0.42 & 1.48 \\
Hard waste & 0.11 & 1.35 & 1.55 & 2.65
\end{tabular}

\section{Conclusion}

The universal production of biofuels has increased radically in the past few years, primarily due to increase in oil prices, national security concerns, environmental considerations and the efforts to revitalize rural communities. India is one of the countries having a huge number of textile industries. The objective of physical pretreatment is to reduce the fibre size and crystallinity, increasing the surface area, reducing the degree of polymerization and shearing the biomass. Choice of pretreatment processes of lignocellulosic biomass is an extremely important step in the synthesis of biofuels. The current study focussed on microwave pretreatment so as to avoid degradation of hemicelluloses and to improve the pentose yield. Among various methods available for the lignocellulose hydrolysis, the current study employed the cellulase hydrolysis and hence an imprerical polynomial model for the production of cellulase enzyme by $T$. reesei was designed using the Box-Behnken design. The simultaneous saccharification and fermentation yields $2.65 \%$ of ethanol from MW irradiated cotton waste. This study thus establishes that the cotton waste from the textile mills can be converted into valuable product for a variety of industrial application.

Acknowledgements. We are grateful to funding organization Department of Biotechnology (DBT), Government of India for the financial assistance. 


\section{REFERENCES}

[1] Alvira, P., Tomás-Pejó, E., Ballesteros, M., Negro, M. J.(2010): Pretreatment technologies for an efficient bioethanol production process based on enzymatic hydrolysis: a review - Bioresource Technology 101(13): 4851-4861.

[2] ASTM (American Standards Test Methods) (1995): Standard test method for determination of Cellulose and Hemicellulose in biomass - ASTM E 1721-95 ASTM, Philadelphia, Pennsylvania.

[3] Azuma, J.I., Tanaka, F., Koshijima, T. (1984): Enhancement of enzymatic susceptibility of lignocellulosic waste by microwave irradiation - Journal of fermentation technology 62: 377-384.

[4] Das, S., Bhattacharya, A., Haldar, S., Ganguly, A., Gu, S., Ting, Y. P., et al. (2015): Optimization of enzymatic saccharification of water hyacinth biomass for bio-ethanol: comparison between artificial neural network and response surface methodology Sustain. Mater. Technol. 3: 17-28.

[5] Duarte, J.C., Rodrigues, J.A., Moran, P.J., Valenca, G.P., Nunhez, J.R. (2013): Effect of immobilized cells in calcium alginate beads in alcoholic fermentation. AMB Express 3(1):31.

[6] Elkund, R., Zacchi, G. (1995): Simultaneous saccharification and fermentation of steamed pretreated willow - Enzyme Microbial Technology 17(3):255-259.

[7] Galbe, M., Zacchi, G. (2002): A review of the production of ethanol from softwood Appl. Microbiol. Biotechnol. 59: 618-628.

[8] Hahn-Hagerdal, B., Galbe, M., Gorwa-Grauslund, M.F., Liden, G., Zacchi, G. (2006): Bioethanol - the fuel of tommrow from the residues of today - Trends in Biotechnology 24:549-556.

[9] Hasunuma, T., Kondo, A. (2012): Consolidadted bioprocessing ans simultaneous sachaarification and fermentation of lignocellulosic to ethanol with thermotolerant teast strains - Process Biochem 47(9): 95-101.

[10] Hu, Z., Wen, Z. (2008): Enhancing enzymatic digestibility of switchgrass by microwaveassisted alkali pretreatment. - Biochemical Engineering Journal 38(3): 369-378.

[11] Jackowiak, D., Frigon, J. C., Ribeiro, T., Pauss, A., Guiot, S. (2011): Enhancing solubilisation and methane production kinetic of switchgrass by microwave pretreatment, Bioresource Technology - 102: (3): 3535-3540.

[12] Jørgensen, H., Kristensen, J.B., Felby, C. (2007): Enzymatic conversion of Lignocellulose into fermentable sugars: challenges and opportunities - Biofuels, Bioproduction and Biorefining 1:119-134.

[13] Keshwani, D. R., Cheng, J. J., Burns, J. C., Chiang, V. (2007): Microwave pretreatment of switchgrass to enhance enzymatic hydrolysis, North Carolina State University.

[14] Kitchaiya, P., Intanakul, P., Krairiksh, M. (2003): Enhancement of enzymatic hydrolysis of lignocellulosic wastes by microwave pretreatment under atmospheric pressure Journal of Wood Chemistry and Technology 23: 217-225.

[15] Lin, Y.C., Lin, J.F., Hsiao, Y.H., Hsu, K.H. (2012): Soybean oil for biodiesel production assisted by a microwave system and sodium methoxide catalyst - Sustain. Environ. Res. 22(4): 247-254.

[16] Miller, G. L. (1959): Use of dinitrosalicylic reagent for determination of reducing sugar Analytical Chemistry 31:426-428.

[17] Newnham, R. E., Jang, S. J., Xu, M., Jones, F. (1991): Fundamental interaction mechanisms between microwaves and matter. - In: Clark, D. E., Gac, F. D., Sutton, W. H. (Eds.) Ceramic Tranctions, Microwaves: Theory and Application in Materials Processing, vol. 21, America Ceramic Society, Westerville, Ohio, USA.

[18] Nibedita Sarkar, Sumanta Kumar Ghosh, Satarupa Bannerjee, Kaustav Aikat (2012): Bioethanol production from agricultural wastes: An overview - Renewable Energy 37:1927. 
[19] Ooshima, H., Aso, K., Harano, Y., Yamamoto, T. (1984): Microwave treatment of cellulosic materials for their enzymatic hydrolysis - Biotechnology Letters 50:289-94.

[20] Pan, X., Arato, C., Gilkes, N., Gregg, D., Mabee, W., Pye, K., Xiao, Z., Zhang, X. Saddler, J. (2005): Biorefining of softwoods using ethanol organosolv pulping: preliminary evaluation of process streams for manufacture of fuel-grade ethanol and coproducts - Biotechnology and Bioengineering, 90: 473-481.

[21] Philippidis, G.P., Smith, T.K. (1995): Limiting factors in simultaneous saccharification and fermentation process for conversion of cellulosic biomassto fuel ethanol. - Appl. Biochem and Biotech 51/52:117-124.

[22] Raj, C. S., Arul, S., Sendilvelan, S., Saravanan, C. G. (2009): Bio Gas from Textile Cotton Waste - An Alternate Fuel for Diesel Engines - The Open Waste Management Journal 2:1-5.

[23] Shi, J., Pu, Y., Yang, B., Ragauskas, A., Wyman, C. E. (2011) Comparison of microwaves to fluidized sand baths for heating tubular reactors for hydrothermal and dilute acid batch pretreatment of corn stover. - Bioresource Technology 102(10): 59525961.

[24] Taherzadeh, M.J., Karimi, K. (2007): Enzymatic-based hydrolysis processes for ethanol from lignocellulosic materials: A Review - Bioresources 2:707-738.

[25] Tengborg, C. (2000): Bioethanol production: Pretreatment and enzymatic hydrolysis of softwood. Ph.D. Thesis, Lund University, Sweden.

[26] Tomás-Pejó, E., García-Aparicio, M., Negro, M. J., Oliva, J. M. and Ballesteros, M. (2009): Effect of different cellulase dosages on cell viability and ethanol production by Kluyveromyces marxianus in SSF processes - Bioresource Technology 100: 890- 895.

[27] Venkatramanan, V., Aravinth, S., Santhoshprabhu, C., Nithya, M., Sathyabama, K. (2014): Bioethanol Production from Cotton Waste using Cellulase Extracted from Fusarium (94 species) - International Journal of ChemTech Research 6 (9): 4061 - 4069.

[28] Williams, M. B., Darwin, R. H. (1950): Colorimetric determination of ethyl alcohol Anal. Chem 22:1556-1561.

[29] Zhao, Q.-X., Zi, L.-H., Bai, F.-W., Lin, H.-L., Hao, X.-M., Yue, G.-J., Ho, N. W. Y. (2012): Bioethanol from Lignocellulosic Biomass- Adv Biochem Engin/Biotechnol 128: $25-51$.

[30] Zhu, J. Y., Pan, X. J., Wang, G. S., Gleisner, R. (2009): Sulphite pretreatment (SPORL) for robust enzymatic saccharification of spruce and red pine - Bioresource Technology 100:2411-2418.

[31] Zhu, S. D. (2005): Pretreatment by microwave/alkali of rice straw and its saccharification and fermentation ethanol production [Ph.D. thesis], Huazhong Agriculture University, Wuhan, China. 